História e imagem: uma abordagem sobre emoção a partir da fonte visual

History and image: an approach about emotion from the visual source

\title{
Elaine Schmitt
}


Resenha do livro: DIDI-HUBERMAN, Georges. Que emoção! Que emoção?. Tradução Cecília Ciscato. 2. ed. São Paulo: Ed. 34, 2018.

A obra “Que emoção! Que emoção?”, traduzida para o português por Cecília Ciscato, é um ensaio-conferência de Georges Didi-Huberman, lançado pela primeira vez em 2016, com reedição em 2018. No breve texto, que aborda autores ocidentais como Darwin, Nietzsche, Hegel e Sartre, o filósofo e historiador de arte pretende pensar as emoções de maneira introdutória e a partir do ato emocionado de chorar.

O choro, essa emoção manifestada em lágrimas, é o ponto de partida da narrativa que propõe, também, a observação de antigos retratos de crianças e desenhos que ilustram expressões faciais de animais e seres humanos, além de fotografias de eventos como velórios, obras de artes e cenas de filmes. São imagens que nos ajudam a perceber semelhanças históricas sobre o jeito de emocionar-se. Com isso, Didi-Huberman chama atenção para a capacidade que temos de não somente expressar, da mesma forma, as mesmas emoções, mas de também aprender, pela passagem do tempo, códigos sociais e modos culturais comuns e legíveis à nossa comunidade.

Diante da imagem de uma criança que chora - foto utilizada na obra "A expressão das emoções no homem e nos animais”, de Charles Darwin, de 1872, o autor incita provocações sobre os efeitos, sentidos e desdobramentos dos “impasses” que sentimos, enquanto seres vivos, ao emocionarmos. Também nos recorda que Darwin teria descrito as emoções como algo pejorativamente primário, uma vez que apenas animais, crianças, mulheres, velhos e todos aqueles que se distanciam da imagem do homem branco europeu vivenciam (DIDI-HUBERMAN, 2018, p. 15). A intenção de compreender os motivos que constituem as emoções socialmente, enquanto gestos primitivos ou não, serve também como ressignificação da visão ultrapassada e dualista de muitos estudiosos e cientistas, que insistem na divisão. Nesse sentido, Didi-Huberman (2018, p. 32) cita também a superação desse modelo cartesiano no âmbito das ciências humanas, dado a partir do momento em que as emoções passaram para o ângulo da História Cultural e que abrange elementos até então memorizados pelo universo científico como as relações, os costumes, as linguagens e as representações.

Se em uma primeira análise a emoção sentida foi entendida como circuito de impasses na linguagem, no pensamento e na ação, sugere o autor que, em um segundo momento, e de acordo com Maurice Merleau-Ponty, era preciso 
mudar radicalmente essa visão. Ao contrário de "impasse", o evento afetivo da emoção causaria uma "abertura efetiva": um tipo de conhecimento sensível e de transformação ativa do mundo, mesmo que nem sempre consciente e representada ${ }^{2 "}$ (DIDI-HUBERMAN, 2018, p. 26).

No que diz respeito ao campo de estudos, sabemos que teóricos e teóricas das emoções vêm mapeando as armadilhas da escrita que separa corpos de teorias e salientando verossimilhanças entre emoção e estrutura social, no qual emoção possui em si mesma a capacidade de reestruturar sentidos sociais. $\mathrm{Ou}$ seja, trata-se de ter consciência da quantidade de formas e do longo tempo de existência com quais as emoções podem se manifestar, tanto quanto diferença quanto como reprodutora social:

[...] as emoções passam por gestos que fazemos sem nos dar conta de que vêm de muito longe no tempo. Esses gestos são como fósseis em movimento. Eles têm uma história muito longa - e muito inconsciente. Eles sobrevivem em nós, ainda que sejamos incapazes de observá-los em nós mesmos (DIDI-HUBERMAN, 2018, p. 21).

Uma das chaves de compreensão sobre como a emoção foi historicamente (mal) interpretada, aponta Didi-Huberman, pode ser encontrada nos estudos lógicos de Aristóteles, que subtraiu a potência da palavra páthos para "voz passiva”. Em seu famoso exemplo "eu corto, eu queimo" veríamos ilustrada a voz ativa, em ação. Ao dizer "eu sou cortado, eu sou queimado", entretanto, veríamos a voz passiva, "em páthos”. A partir dessa reflexão, entendemos melhor como o fenômeno da emoção foi relacionado à paixão, passividade ou impossibilidade de agir. Herrera Gomez (2007) chama tal dualidade de "pensamento polarizante", um pensamento que estabeleceoposições entre razão e emoção, natureza e cultura, masculino e feminino, positivo e negativo, bem e mal, verdade e mentira, etc., e que acaba por ocultar a ampla gama de matizes e fatores que estão inter-relacionados em todos os processos do conhecimento e da investigação científica. Ignorar esses importantes elementos, aconselha a autora, seria por si só reducionista e empobrecedor.

Percorrendo a história da construção do conhecimento, Didi-Huberman (2018, p. 23) afirma que a polarização que comportou a emoção isolada na esfera da passividade foi repensada com Hegel, quando devolveu ao páthos a "dignidade diante do logos" e chamou-o, inclusive, de privilégio dos seres 
vivos. Assim, tornou-se possível pensar emoção não mais como um "estado de pura e simples passividade", uma vez que as expressões de sentimentos - sejam grupais ou individuais - são "signos de expressões inteligíveis" manifestadas para nós mesmos no momento em que os exprimimos para os outros e por conta dos outros. Ou seja, trata-se essencialmente de uma simbologia, carregada de mais complexidade, potência e poder político que se imaginava: "[...] se não podemos fazer política efetiva apenas com sentimentos, tampouco podemos fazer boa política desqualificando nossas emoções, isto é, as emoções de toda e qualquer pessoa, as emoções de todos em qualquer um" (DIDI-HUBERMAN, 2018, p. 38).

Para Moraña (2012), os dispositivos de subjetivação que ajudam a enriquecer nossa relação com o mundo passam por três ecologias: a ambiental, a social e a psíquica. Com isso, a autora acrescenta à discussão a possibilidade de as emoções comportarem expressões e intensidades que fogem da discursividade, mas que, mesmo assim, encontram eco no meio social por serem, justamente, práticas sociais e culturais assumidas desde o corpo social. De tal modo, mais que investigar o que são as emoções, deveríamos nos perguntar o que fazem hoje, ante um mundo em que emoções e expressões emocionais alcançam índices de grande intensidade e negatividade.

A História das Artes Visuais surge, nesse sentido, como um campo potente de compreensões e reflexões sobre essas manifestações. Assim como a pintura, a escultura e o cinema, a fotografia, no exemplo de Didi-Huberman (2018, p. 35), pode ser lida como uma grande história das emoções figuradas e dos gestos emotivos que Aby Warburg denominou "fórmulas patéticas".

E no que diz respeito à especificidade da imagem fotográfica, Menezes (2003) encontra na História da Arte um campo de conhecimento (o primeiro!) que reconheceu o sistemático potencial cognitivo da imagem visual. Com isso, deslocamos "visualidade" para "fontes visuais" em uma tentativa de ultrapassar o horizonte da pura visualidade e das implicações da singularidade na criação artística para encontrar significações antropológicas, geográficas e históricas:

[Aos] Estudos de manifestações 'imagéticas' da cultura se acrescentou a necessidade de compreender os mecanismos variadamente localizados de produção de sentido - sentido dialógico, portanto socialmente construído e mutável e não préformado ou imanente à fonte visual (MENEZES, 2003, p. 16-17). 
Didi-Huberman (2018, p. 34), ao trazer fotografias para sua obra enquanto fontes visuais - e com significações amplas de antigos gestos -, parece concordar com Menezes quanto ao valor participativo das imagens em nossas relações sociais e como expressões coletivas das emoções que atravessam a história.

Se as emoções, aqui capturadas em imagens, são, também, repetições performáticas, tradições culturais, códigos simbólicos ensinados de um para o outro em direção à coletividade, como a veremos em um mundo globalizado, de sincretismo, transição, que faz ressurgir o fundamentalismo e o nacionalismo eurocêntrico? A provocação, já estabelecida por Hall (2006), serve como apontamento de um dos desafios que enfrentaremos na investigação social pós-moderna, um viés que coloca também em evidência a política das emoções e a potência histórica da fonte visual.

\section{Referências}

GOMEZ, Coral Herrera. La construción sociocultural del amor romântico. 4. ed. Madrid: Ed. Fundamentos, 2007.

HALL, Stuart. A identidade cultural na pós-modernidade. 11 ed. Rio de Janeiro: DP \& A, 2006. Disponível em: http://faa.edu.br/portal/PDF/livros_eletronicos/ psicologia/a_Identidade_Cultural_Da_Pos_Modernidade.pdf. Acesso em: 2 fev. 2019.

MORAÑA, Mabel. El afecto en la caja de herramientas. In: MORAÑA, Mabel; PRADO, Ignacio M. S. (ed.). El lenguaje de las emociones. Madrid: Iberoamerican, 2012. p. 313-335.

MENEZES, Ulpiano T. B. Fontes visuais, cultura visual, história visual. Balanço provisório, propostas cautelares. Revista Brasileira de História, São Paulo, v. 23, n. 45, p.11-36, 2003. Disponível em: http://www.scielo.br/scielo.php?script=sci arttext\&pid=S010201882003000100002\&lng=en\&nrm=iso. Acesso em: 2 fev. 2019. 


\section{Notas}

${ }^{1}$ Universidade Federal de Santa Catarinha.

${ }^{2}$ Esse pensamento foi fortemente influenciado pela psicanálise freudiana e os estudos do inconsciente. 